\title{
Synthesis and Reduction Kinetics of Five Ibuprofen-Nitroxides for Ascorbic Acid and Methyl Radicals
}

\author{
Kota Sasaki, ${ }^{a}$ Tomohiro Ito, ${ }^{a}$ Hirotada G. Fujii, ${ }^{b}$ and Shingo Sato ${ }^{* a}$ \\ ${ }^{a}$ Graduate School of Science and Engineering, Yamagata University; 4-3-16 Jonan, Yonezawa, Yamagata 992-8510, \\ Japan: and ${ }^{b}$ Center for Medical Education, Sapporo Medical University; Sapporo 060-8556, Japan. \\ Received April 20, 2016; accepted July 31, 2016
}

The hybrid compounds 1-5 comprised of five nitroxides with ibuprofen were synthesized and their reduction rate for ascorbic acid (AsA) and methyl radicals were measured in comparison with 3-hydroxytetramethylpyrrolidine-1-oxyl (PROXYL) 6. The rate constants in reduction reaction with 200-fold excess of AsA were determined in following order: $1(0.42 \pm 0.06), 3(0.17 \pm 0.06), 2(0.10 \pm 0.05)$, and $6\left(0.09 \pm 0.02 \mathrm{M}^{-1} \mathrm{~s}^{-1}\right)$. The remaining two sterically shielded nitroxides 4 and 5 scarcely reacted with AsA. In the reaction with the more reactive methyl radicals, produced by 200 -fold excess of Fenton's reagent, the reduction rates of 2, 4, and 5 were in the following decreasing order: $2(1.1 \pm 0.2), 4(0.76 \pm 0.09)$, and $5\left(0.31 \pm 0.03 \mathrm{M}^{-1} \mathrm{~s}^{-1}\right)$.

Key words Ibuprofen-nitroxide; reduction kinetics; ascorbic acid; methyl radical; Fenton reaction; electron paramagnetic resonance intensity

The representative nitroxide radicals, a six-memberedring nitroxide, tetramethylpiperidine-1-oxyl (TEMPO), and a five-membered-ring nitroxide, tetramethylpyrrolidine-1-oxyl (PROXYL), have been used as in-vivo probes. Recently, various nitroxides in which the tetramethyl groups around the nitroxyl group were replaced by bulkier groups have been synthesized. They had different reduction rates for reductants such as ascorbic acid (AsA), and these were applied as an invivo probe. ${ }^{1-17)}$ The rate constant of reduction of a nitroxide probe in vitro is expected to be a guideline of its half-life in vivo. ${ }^{9-11)}$ The rate constants of them are greatly different and could not measure under the same conditions.9,10,17) For the nitroxides resistant to AsA, we planned to examine the measurement of their rate constants using methyl radicals formed by Fenton reaction. The balance between their sensitivity for reductants and half-life is important for use of nitroxide as an in-vivo probe. TEMPO radical is highly sensitive for reductants and a good detection reagent for AsA, ${ }^{5,11)}$ but, its half-life as an in-vivo probe was too short and unusable. ${ }^{14)}$

It has been shown that ibuprofen-PROXYL passed through the blood-brain barrier (BBB) in mice and was indicated the anti-inflammatory action in inflamed mice brains. Real-time changes in the redox status of mice brains were successfully visualized by magnetic resonance imaging (MRI) and electron paramagnetic resonance (EPR) imaging. Both shows a func- tionality as a theranostic compound. ${ }^{18)}$ However, for exploring the redox status of brain, nitroxides with different reduction rate for reductants such as reactive oxygen species (ROS) or vitamin $\mathrm{C}$ or $\mathrm{E}$ are required. Five nitroxides with different reduction activities and their condensates with ibuprofen were synthesized (Fig. 1). The reduction reactivity of the five ibuprofen-nitroxides were measured by addition of AsA, and for the reduction-resistant nitroxides by the addition of the methyl radicals produced by the Fenton reaction. The reduction rate constants of the five ibuprofen-nitroxides for AsA or methyl radicals were determined and compared with the suitable time-dependent reduction-decay curve.

\section{Results and Discussion}

Synthesis Six nitroxides (6-11) were synthesized by the synthetic methods shown in Chart S1. Sterically shielded nitroxides 7, $\mathbf{1 0}$ and $\mathbf{1 1}$ were synthesized according to the method established by Yamada's group ${ }^{4-7)}$ and Rajca's group. $^{9-11)}$ Since there were some low-yield reaction steps in the synthesis of the sterically shielded nitroxides $(\mathbf{7}, \mathbf{1 0}, \mathbf{1 1})$, the reaction conditions were partially improved and synthesis was achieved.

Nitroxides with tetramethyl groups $\mathbf{6 , 8}$ and $\mathbf{9}$ were synthesized by conventional methods. ${ }^{19-21)}$

The ibuprofen-nitroxides $\mathbf{1}-\mathbf{5}$ were synthesized by a con-

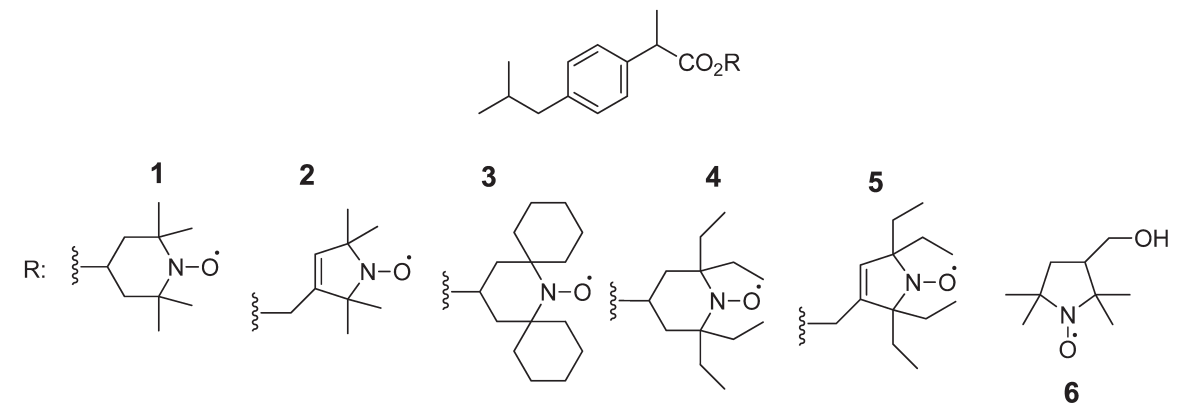

Fig. 1. Five Ibuprofen-Nitroxide Compounds (1-5) and 3-Hydroxymethyltetramethylpyrrolidin-1-oxyl (6) 
densation reaction using dicyclohexylcarbodiimide (DCC) and $N, N$-dimethyl-4-aminopyridine (DMAP) in quantitative yields.

\section{Measurements}

${ }^{1}$ H-NMR and EPR Spectra of 1-6 The purity of the ibuprofen-nitroxides $\mathbf{1 - 5}$ was determined by ${ }^{1} \mathrm{H}-\mathrm{NMR}$ and EPR spectroscopies (Figs. S1-S11). In ${ }^{1} \mathrm{H}-\mathrm{NMR}$ spectroscopy the assignment was achieved as a hydroxylamine by adding excess of hydrazobenzene. EPR spectra of ibuprofen-nitroxides 3-5 in dimethyl sulfoxide (DMSO) show triplet patterns due to ${ }^{14} \mathrm{~N}$ hyperfine splitting, $a_{\mathrm{N}}=1.43-1.53 \mathrm{mT}$, and $g$-values of about 2.006, similar to those for tetramethyl-linked $\mathbf{1}$ and $\mathbf{2}$ (Figs. S6-S11). EPR line-widths of nitroxides with tetramethyl groups 1, 2 and 6 were $0.086-0.096 \mathrm{mT}$ and those of nitroxides with the more sterically hindered groups 3, 4 and 5 were broad, 0.103-0.198 $\mathrm{mT}^{18}$ ) (Table 1). DMSO was used as solvent for the measurement of the reduction kinetics.

Partition Coefficients $\left(\log P_{\mathrm{o} / \mathrm{w}}\right)$ of Nitroxides 1-6 (Table S1) Partition coefficients $\left(\log P_{\mathrm{o} / \mathrm{w}}\right)$ of nitroxides $\mathbf{1}-\mathbf{6}$ between $n$-octanol and phosphate buffer solution (PBS) (0.1 M, pH 7.4) were measured by EPR spectroscopy and compared. ${ }^{7-9)}$ Since ibuprofen-nitroxides were insoluble in PBS due to their lipophilicity, each nitroxide was added in a mixture of $1 \mathrm{~mL}$ of $n$-octanol and $1 \mathrm{~mL}$ of $\mathrm{PBS}(0.1 \mathrm{M}, \mathrm{pH} 7.4)$, and the resultant mixture was mixed vigorously for $1 \mathrm{~h}$, and then the mixture was centrifuged at $3000 \mathrm{rpm}$ for $5 \mathrm{~min}$. Both $n$-octanol and PBS were subjected to the EPR measurement. Due to the li-

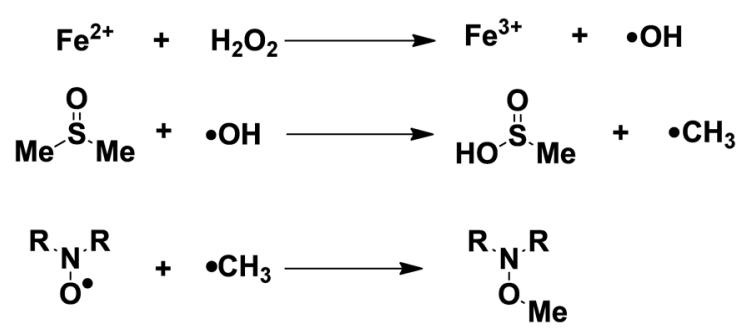

Chart 1. Methyl Etherfication of the Nitroxide Radical by Fenton Reaction

Table 1. Values of $g$-Factors and Nitrogen $h f_{c}$ Constants $a_{\mathrm{N}}(\mathrm{mT})$ and Line Width $(\mathrm{mT})$ of Six Nitroxides ( $2 \mathrm{~mm}$ in DMSO)

\begin{tabular}{cccc}
\hline \hline Compound & $g$ & $a_{\mathrm{N}}(\mathrm{mT})$ & Line width $(\mathrm{mT})$ \\
\hline $\mathbf{1}$ & 2.0066 & 1.56 & 0.096 \\
$\mathbf{2}$ & 2.0069 & 1.47 & 0.086 \\
$\mathbf{3}$ & 2.0060 & 1.53 & 0.198 \\
$\mathbf{4}$ & 2.0063 & 1.46 & 0.141 \\
$\mathbf{5}$ & 2.0068 & 1.43 & 0.103 \\
$\mathbf{6}$ & 2.0069 & 1.47 & 0.088 \\
\hline
\end{tabular}

Table 2. Second-Order Rate Constants, $k\left(\mathrm{M}^{-1} \mathrm{~s}^{-1}\right)$, for Initial Rates of Reduction of Four Nitroxides $(20 \mu \mathrm{M})$ with 200-Fold Excess of AsA at $295 \mathrm{~K}$, Based on the Fig. 2 (Mean \pm S.D., $n=3$ )

\begin{tabular}{ccc}
\hline \hline Compound & $k\left(\mathrm{M}^{-1} \mathrm{~s}^{-1}\right)$ & $R^{2}$ \\
\hline $\mathbf{1}$ & $0.42 \pm 0.07$ & 0.9998 \\
$\mathbf{2}$ & $0.10 \pm 0.05$ & 0.9815 \\
$\mathbf{3}$ & $0.17 \pm 0.06$ & 0.9753 \\
$\mathbf{6}$ & $0.09 \pm 0.02$ & 0.9787 \\
\hline
\end{tabular}

pophilicity of the ibuprophen-nitroxides, nitroxide-radicals in compounds $\mathbf{2}-\mathbf{5}$ were no detectable in PBS. $\log P_{\mathrm{o} / \mathrm{w}}$ of $\mathbf{1}$ was also 3.49 , very lipophilic.

Reduction Rate Constants, $k\left(\mathrm{M}^{-1} \mathrm{~s}^{-1}\right)$ for 200-Folds Excess AsA The rates of reduction for nitroxides 1-5 were studied under pseudo-first-order conditions using a 200 -fold excess of AsA in DMSO. Second-order rate constants, $k$ were obtained by monitoring the decay of the low-field EPR peak height of nitroxides/peak height of the Mn marker from $2 \mathrm{~min}$ to $10 \mathrm{~min}$ after reaction at $295 \mathrm{~K}$ (Fig. 2, Table 2).

The reduction reaction of five ibuprofen-nitroxides and 3-hydroxymethyl-2,2,5,5-tetramethylpyrrolidin-1-oxyl (6) with 200 -fold excess of AsA, showed that the sterically shielded nitroxides $\mathbf{4}$ and $\mathbf{5}$, linked with tetraethyl groups, were scarcely subject to the reduction. The hybrid compounds comprised of ibuprofen and the more reactive six-membered ring compounds $(\mathbf{1}, \mathbf{3})$ or the tetramethyl group-linked five-membered ring compounds $(\mathbf{2}, \mathbf{6})$ were subjected to the reduction, and had the order $\mathbf{1}>\mathbf{3}>\mathbf{2}>\mathbf{6}$. Rate constant was calculated about 1, 2, 3, and 6 which showed the appropriate decay curve. Tetramethylpiperidine nitroxide $\mathbf{1}$ was 2.47 times faster than dicyclohexylpiperidine nitroxide $\mathbf{3}$, which was 1.70 times faster than tetramethylpyroline nitroxide 2 , which in turn was 1.11 times faster than tetramethylpyrrolidine nitroxide 6. It was assumed that the six-membered ring nitroxides $\mathbf{1}$ and $\mathbf{3}$ are ready to react with AsA compared to the five-membered ring nitroxide because they take the same chair-form. The decay by the reduction of 3 was variable and $R^{2}$ was low because of the EPR spectrum was unstable and signal width of the splitting pattern was broad.

Reduction Rate Constants, $k\left(\mathrm{M}^{-1} \mathrm{~s}^{-1}\right)$ for 200-Fold Excess Methyl Radicals Produced by Fenton's Reagent As the reaction of AsA with the sterically shielded nitroxides 4 and 5 was limited, a more reactive radical was necessary to obtain more exact rate constants. One such readily preparable radical is the methyl radical, which is produced by the Fenton reaction $^{22-25)}$ (Chart 1).

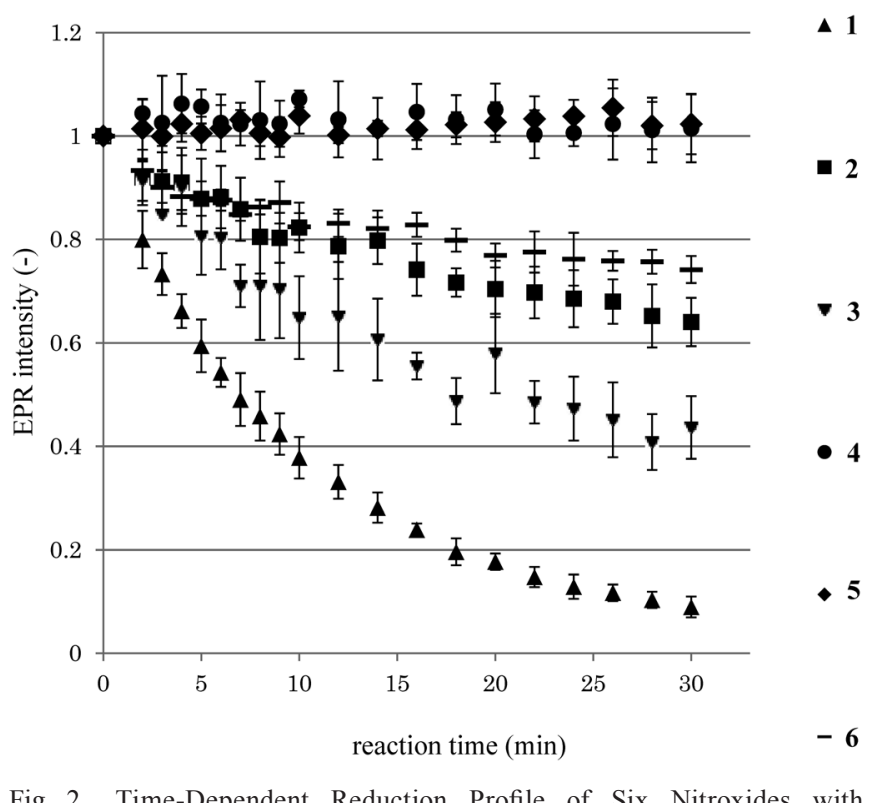

Time-Dependent Reduction Profile of Six Nitroxides with 200 -Fold AsA in DMSO at $295 \mathrm{~K}$

Each point is the mean of three experiments ( \pm S.D.). 


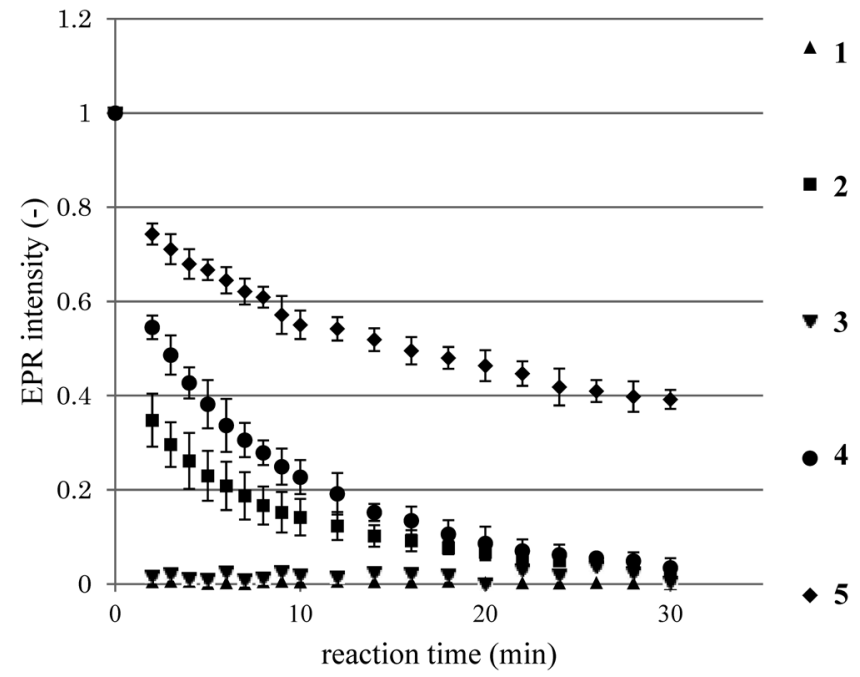

Fig. 3. Time-Dependent Reduction Profile of Five Nitroxides with Methyl Radicals

Each point is the mean of three experiments $( \pm$ S.D.).

Table 3. Second-Order Rate Constants, $k\left(\mathrm{M}^{-1} \mathrm{~s}^{-1}\right)$, for Initial Rates of Reduction of Three Nitroxides $(20 \mu \mathrm{M})$ with 200-Fold Fenton Reagents at $295 \mathrm{~K}$, Based on the Fig. 3 (Mean \pm S.D., $n=3$ )

\begin{tabular}{ccc}
\hline \hline Compound & $k\left(\mathrm{M}^{-1} \mathrm{~s}^{-1}\right)$ & $R^{2}$ \\
\hline $\mathbf{2}$ & $1.1 \pm 0.2$ & 0.9997 \\
$\mathbf{4}$ & $0.76 \pm 0.09$ & 0.9998 \\
$\mathbf{5}$ & $0.31 \pm 0.03$ & 0.9933 \\
\hline
\end{tabular}

For the nitroxides resistant to AsA, the methyl radicals produced by the Fenton reaction were used. Rate constant, $k$ was determined in the same way to that of AsA. To determine the concentration and conditions of the Fenton's reagent to be used in the reaction with the nitroxides, a pre-examination using 20-, 100-, and 200-fold excess of Fenton's reagent with $20 \mu \mathrm{M}$ nitroxide 5 was carried out. It was found that 200 -fold of reagent gave the best decay curve. The structure of the methyl adduct product was confirmed (see Experimental, compound 12). The reaction of nitroxide with methyl radicals is irreversible, unlike the conversion of nitroxide by AsA into hydroxylamine. The reactions of the five ibuprofen-nitroxides with 200-fold excess of Fenton's reagent were conducted (Fig. 3). Since the appropriate decay curves were showed, the rate constants were calculated for 2, 4, and $\mathbf{5}$. Nitroxides $\mathbf{1}$ and 3 reacted immediately. The remaining sterically shielded nitroxides $(\mathbf{2}, \mathbf{4}, \mathbf{5})$, which had hardly reacted with AsA, reacted in the order $\mathbf{2}, \mathbf{4}$, and $\mathbf{5}$. There was not a large difference between the rate constants. Nitroxides $\mathbf{2}$ and $\mathbf{4}$ reacted within $30 \mathrm{~min}$, however, in the most sterically shielded nitroxide $\mathbf{5}$, $25 \%$ had not been reduced after $30 \mathrm{~min}$. It was surprising that 5 was resistant not only to AsA but also to the labile methyl radicals.

\section{Conclusion}

Five ester-linked hybrid compounds between ibuprofen and five nitroxides with a variety of nitroxyl-protecting groups were synthesized and the reactivities to AsA and methyl radicals were measured. For three hybrid compounds and 6, moderate decay curves for 200-fold excess AsA were determined, with the reduction rate constants in following order: $1(0.42 \pm 0.06), 3(0.17 \pm 0.06), 2(0.10 \pm 0.05)$, and 6 $\left(0.09 \pm 0.02 \mathrm{M}^{-1} \mathrm{~s}^{-1}\right)$. For the AsA-resistant compounds, moderate decay curves with 200 -fold excess methyl radicals were determined, with the reduction rate constants in the following decreasing order: $2(1.1 \pm 0.2), 4(0.76 \pm 0.09)$, and 5 $\left(0.31 \pm 0.03 \mathrm{M}^{-1} \mathrm{~s}^{-1}\right)$ (Table 3 ). Since the rate constant of 2 was determined for AsA and methyl radicals as $0.10 \pm 0.05$, and $1.1 \pm 0.2$, respectively, it is assumed that reduction ability of 200-fold excess Fenton's reagent for ibuprofen-nitroxides is 10 times higher than that of 200-fold excess AsA. Although each reduction rate constant was here determined using DMSO as a solvent due to the lipophilicity of the ibuprofen-nitroxides, since that of 6 for AsA in PBS was $0.12 \pm 0.003 \mathrm{M}^{-1} \mathrm{~s}^{-1}$ and analogous to $0.09 \pm 0.02 \mathrm{M}^{-1} \mathrm{~s}^{-1}$ in DMSO, it was demonstrated that this method using both AsA and methyl radical as a reductant is also available in PBS for the measurement of the reduction rate constants of the nitroxide derivatives with various reactivity.

\section{Experimental \\ Synthesis}

\section{Materials and Apparatus}

All starting materials and reagents were purchased from Wako Pure Chemical Industries, Ltd., Osaka, Japan and Sigma-Aldrich, St. Louis, MO, U.S.A. Reactions were monitored by TLC on $0.25-\mathrm{mm}$ silica gel F254 plates (E. Merck, Japan). UV radiation and a 7\% ethanolic solution of phosphomolybdic acid with heating, were used for coloration. Flash column chromatography was performed on silica gel (silicagel 60, 40-50 $\mu \mathrm{m}$, Kanto Chemical Co., Inc., Tokyo, Japan) to separate and purify the reaction products. Melting points were determined using an ASONE micro-melting point apparatus and uncorrected values reported. NMR spectra were recorded on a JEOL ECX-500 spectrometer using $\mathrm{Me}_{4} \mathrm{Si}$ as the internal standard. The ${ }^{1} \mathrm{H}-\mathrm{NMR}$ spectra of the hybrid compounds were measured and assigned for the corresponding hydroxylamines, which were prepared by the reduction of nitroxide radicals under the presence of excess of hydrazobenzene (Wako Pure Chemical Industries, Ltd.). Mass spectra and high-resolution mass spectra (HR-MS) were obtained under electron spray ionization (ESI) conditions on a JEOL JMS-T100LP.

\section{General Procedures}

Synthesis of Nitroxides $\mathbf{6}-\mathbf{- 1 1}$

The nitroxide radicals used in the present study were synthesized by established methods, as shown in Supplementary materials (Chart S1). Nitroxides 6, 7, 8, 9, and $\mathbf{1 0}$ were synthesized via $6,4,1,4$, and 3 steps from tetramethyl-4-piperidone in overall yield of $52,17,85,62$, and $0.8 \%$, respectively. Nitroxide 11 was synthesized via 4 steps from tetraethyl-4-hydroxypiperidine with an overall yield of $6.05 \%$. The synthetic yield of $\mathbf{1 0}$ was very low, $0.8 \%$, because of the change of gemmethyl group to a gem-cyclohexyl group and the subsequent oxidation to nitroxide radical had a low unimprovable yield of 16 and $5.5 \%$, respectively.

Synthesis of $(2,2,6,6$-Tetramethylpiperidin-1-oxyl)-4-yl ( $( \pm)$ 2-( $p$-Isobutylphenyl)propionate (1)

To a solution of ibuprofen (216 mg, 1.05 equiv.) and 3-hydroxymethyl-2,2,5,5-tetramethylpyperidin-1-oxyl (172 mg) in dry $\mathrm{CH}_{2} \mathrm{Cl}_{2}(6 \mathrm{~mL})$, DCC (229 mg, 1.11 equiv.) and DMAP (13.5 mg, 0.111 equiv.) were added and the mixture was stirred 
at room temperature under an Ar atmosphere for $18 \mathrm{~h}$. To the reaction mixture ethyl ether $(20 \mathrm{~mL})$ was added and the resulting precipitates were filtered through a celite pad. The filtrate was evaporated in vacuo and then purified by silica-gel column chromatography ( $n$-hexane/ethyl acetate $=3: 1)$ to give $\mathbf{1}$ $(360 \mathrm{mg}, 100 \%)$ as red crystals.

The other ibuprofen nitroxides 2-5 were synthesized in a similar way to that of $\mathbf{1}$ in quantitative yields.

(2,2,6,6-Tetramethylpiperidin-1-oxyl)-4-yl

Isobutylphenyl)propionate (1)

Red crystals, $m p=48^{\circ} \mathrm{C}$. ESI-MS $(m / z) 362(\mathrm{M}+2 \mathrm{H})^{+}$. ${ }^{1} \mathrm{H}-\mathrm{NMR}\left(\mathrm{CDCl}_{3}\right) \delta$ (ibuprofen moiety) $0.89(6 \mathrm{H}, \mathrm{d}, J=6.8 \mathrm{~Hz}$, $\left.\mathrm{CH}_{3} \times 2\right), 1.47\left(3 \mathrm{H}, \mathrm{d}, J=7.5 \mathrm{~Hz}, 2-\mathrm{CH}_{3}\right), 1.84(1 \mathrm{H}, \mathrm{m}, \mathrm{H} 8), 2.44$ and 2.45 (each $\left.1 \mathrm{H}, \mathrm{s}, \mathrm{CH}_{2}\right), 3.64(1 \mathrm{H}, \mathrm{q}, J=7.5 \mathrm{~Hz}, \mathrm{H} 2), 7.08$ and 7.18 (each $2 \mathrm{H}, \mathrm{d}, J=8.2 \mathrm{~Hz}, \mathrm{ArH} \times 4$ ), (piperidine moiety) 1.13, 1.15, 1.17, 1.18 (each $3 \mathrm{H}, \mathrm{s},-\mathrm{CH}_{3} \times 4$ ), 1.45 and 1.54 (each $1 \mathrm{H}, \mathrm{t}, J=11.6 \mathrm{~Hz}, \mathrm{CH}_{2}$ ), 1.78 and 1.88 (each $1 \mathrm{H}, \mathrm{dt}, J=0.4$, $\left.11.6 \mathrm{~Hz}, \mathrm{CH}_{2}\right), 5.02(1 \mathrm{H}, \mathrm{m},>\mathrm{CH}-)$. HR-MS $\left(\mathrm{ESI}^{+}\right) \mathrm{m} / \mathrm{z}$ : $[\mathrm{M}+$ $2 \mathrm{H}]^{+}$, calcd for $\mathrm{C}_{22} \mathrm{H}_{36} \mathrm{NO}_{3} 362.26952$, found 362.26998 .

(2,2,5,5-Tetramethyl-3-pyrroline-1-oxyl)-3-yl-methyl ( \pm )-2( $p$-Isobutylphenyl)propionate (2)

Pale-yellow crystals, $\mathrm{mp}=45^{\circ} \mathrm{C}$. ESI-MS $(\mathrm{m} / \mathrm{z}) \quad 381$ $(\mathrm{M}+\mathrm{Na})^{+}, 358(\mathrm{M})^{+} .{ }^{1} \mathrm{H}-\mathrm{NMR}\left(\mathrm{CDCl}_{3}\right) \delta$ (ibuprofen moiety) $0.89\left(6 \mathrm{H}, \mathrm{d}, J=6.7 \mathrm{~Hz}, \mathrm{CH}_{3} \times 2\right), 1.51\left(3 \mathrm{H}, \mathrm{d}, J=7.5 \mathrm{~Hz}, 2-\mathrm{CH}_{3}\right)$, $1.83(1 \mathrm{H}, \mathrm{m}, \mathrm{H} 8), 2.43$ and $2.45\left(\right.$ each $\left.1 \mathrm{H}, \mathrm{s}, \mathrm{CH}_{2}\right), 3.72(1 \mathrm{H}, \mathrm{q}$, $J=7.5 \mathrm{~Hz}, \mathrm{H} 2$ ), 7.09 and 7.21 (each $2 \mathrm{H}, \mathrm{d}, J=8.3 \mathrm{~Hz}, \mathrm{ArH} \times 4$ ), (piperidine moiety) 1.11, 1.12, 1.14, 1.15 (each $3 \mathrm{H}, \mathrm{s},-\mathrm{CH}_{3} \times 4$ ), 4.52 and 4.61 (each $\left.1 \mathrm{H}, \mathrm{d}, J=14.1 \mathrm{~Hz}, \mathrm{CH}_{2}\right), 5.33(1 \mathrm{H}$, s, olefin $\mathrm{H}$ ). HR-MS $\left(\mathrm{ESI}^{+}\right.$) calcd for $\mathrm{C}_{22} \mathrm{H}_{32} \mathrm{NO}_{3} 358.23822$, found 358.23819 .

(7-Aza-dispiro[5.1.5.3]hexadec-7-yl-oxyl)-15-yl $\quad( \pm)-2-(p-$ Isobutylphenyl)propionate (3)

Pale-red crystals, $\mathrm{mp}=102^{\circ} \mathrm{C}$. ESI-MS $(\mathrm{m} / \mathrm{z}) 463(\mathrm{M}+\mathrm{Na})^{+}$, $442(\mathrm{M}+2 \mathrm{H})^{+} .{ }^{1} \mathrm{H}-\mathrm{NMR}\left(\mathrm{CDCl}_{3}\right) \delta$ (ibuprofen moiety) 0.88 $\left(6 \mathrm{H}, \mathrm{d}, J=6.8 \mathrm{~Hz}, \mathrm{CH}_{3} \times 2\right), 1.49\left(3 \mathrm{H}, \mathrm{d}, J=6.8 \mathrm{~Hz}, \mathrm{CH}_{3}\right), 1.84$ $(1 \mathrm{H}, \mathrm{m}, \mathrm{H} 8), 2.43$ and 2.45 (each $\left.1 \mathrm{H}, \mathrm{s}, \mathrm{CH}_{2}\right), 3.65(1 \mathrm{H}, \mathrm{q}$, $J=6.8 \mathrm{~Hz}, \mathrm{H} 2$ ), 7.09 and 7.19 (each 2H, d, $J=8.6 \mathrm{~Hz}$, ArH $\times 4)$, (piperidine moiety) $1.00-1.45(11 \mathrm{H}, \mathrm{m}$, cyclohexyl $\mathrm{H})$, 1.51-1.68 (9H, m, cyclohexyl H), 2.24 and 2.35 (each $2 \mathrm{H}$, brdt, $\left.J=12.1 \mathrm{~Hz}, \mathrm{CH}_{2} \times 2\right), 4.19(1 \mathrm{H}, \mathrm{m},>\mathrm{CH}-)$. HR-MS $\left(\mathrm{ESI}^{+}\right)$ calcd for $\mathrm{C}_{28} \mathrm{H}_{42} \mathrm{NNaO}_{3} 463.30624$, found 463.30686 .

(2,2,6,6-Tetraethylpiperidin-1-oxyl)-4-yl (士)-2-( $p$-Isobutylphenyl)propionate (4)

Red powder. ESI-MS $(\mathrm{m} / \mathrm{z}) 439(\mathrm{M}+\mathrm{Na})^{+} .{ }^{1} \mathrm{H}-\mathrm{NMR}\left(\mathrm{CDCl}_{3}\right)$ $\delta$ (ibuprofen moiety) $0.88\left(6 \mathrm{H}, \mathrm{d}, J=6.8 \mathrm{~Hz}, \mathrm{CH}_{3} \times 2\right), 1.47(3 \mathrm{H}$, $\left.\mathrm{d}, J=6.8 \mathrm{~Hz}, 2-\mathrm{CH}_{3}\right), 1.28(1 \mathrm{H}, \mathrm{m}, \mathrm{H} 8), 2.42$ and 2.44 (each $\left.1 \mathrm{H}, \mathrm{s}, \mathrm{CH}_{2}\right), 3.64(1 \mathrm{H}, \mathrm{q}, J=6.8 \mathrm{~Hz}, \mathrm{H} 2), 6.81$ and 7.18 (each $2 \mathrm{H}, \mathrm{d}, J=8.4 \mathrm{~Hz}, \mathrm{ArH} \times 4$ ), (piperidine moiety) 0.78, 0.81, $0.82,0.85$ (each $\left.3 \mathrm{H}, \mathrm{t}, J=7.5 \mathrm{~Hz},-\mathrm{CH}_{2} \mathrm{CH}_{3} \times 4\right), 1.24-1.30(2 \mathrm{H}$, $\left.-\mathrm{CH}_{2} \mathrm{CH}_{3} \times 1\right), 1.60-1.70\left(4 \mathrm{H}, \mathrm{m},-\mathrm{CH}_{2} \mathrm{CH}_{3} \times 2\right), 1.60-1.70(4 \mathrm{H}$, $\left.\mathrm{m},-\mathrm{CH}_{2} \mathrm{CH}_{3} \times 2\right), 1.86\left(2 \mathrm{H},-\mathrm{CH}_{2} \mathrm{CH}_{3} \times 1\right), 1.43$ and 1.97 (each $\left.2 \mathrm{H}, \mathrm{t}, \mathrm{J}=9.1 \mathrm{~Hz}, \mathrm{CH}_{2} \times 2\right), 4.97(1 \mathrm{H}, \mathrm{m},>\mathrm{CH}-)$. HR-MS $\left(\mathrm{ESI}^{+}\right)$ calcd for $\mathrm{C}_{26} \mathrm{H}_{42} \mathrm{NNaO}_{3}$ 439.30624, found 439.30413.

(2,2,5,5-Tetraethyl-3-pyrroline-1-oxyl)-3-ylmethyl ( $( \pm)-2-(p-$ Isobutylphenyl)propionate (5)

Yellow powder. ESI-MS $(\mathrm{m} / \mathrm{z}) 437(\mathrm{M}+\mathrm{Na})^{+} \cdot{ }^{1} \mathrm{H}-\mathrm{NMR}$ $\left(\mathrm{CDCl}_{3}\right) \delta$ (ibuprofen moiety) 0.76 and 0.82 (each $3 \mathrm{H}, \mathrm{d}$, $\left.J=6.8 \mathrm{~Hz}, 8-\mathrm{CH}_{3} \times 2\right), 1.50\left(3 \mathrm{H}, \mathrm{d}, J=6.8 \mathrm{~Hz}, 2-\mathrm{CH}_{3}\right), 1.82$ $(1 \mathrm{H}, \mathrm{m}, \mathrm{H} 8), 2.41$ and 2.43 (each $\left.1 \mathrm{H}, \mathrm{s}, \mathrm{CH}_{2}\right), 3.72(1 \mathrm{H}, \mathrm{q}$, $J=6.8 \mathrm{~Hz}, \mathrm{H} 2$ ), 6.81 and 7.19 (each $2 \mathrm{H}, \mathrm{d}, J=6.8 \mathrm{~Hz}, \mathrm{ArH} \times 4$ ), (piperidine moiety) 0.87 and 0.89 (each $6 \mathrm{H}$, brs, $-\mathrm{CH}_{2} \mathrm{CH}_{3} \times 4$ ),
1.40-1.62 (8H, m, $\left.-\mathrm{CH}_{2} \mathrm{CH}_{3} \times 4\right), 4.43$ and 4.58 (each $1 \mathrm{H}, \mathrm{d}$, $\left.J=14.4 \mathrm{~Hz}, \mathrm{CH}_{2}\right), 5.24\left(1 \mathrm{H}, \mathrm{s}\right.$, olefin H). HR-MS $\left(\mathrm{ESI}^{+}\right)$calcd for $\mathrm{C}_{26} \mathrm{H}_{40} \mathrm{NNaO}_{3}$ 437.29059, found 437.28977.

(1-Methoxy-2,2,5,5-tetramethyl-3-pyrrolin)-3-ylmethyl ( \pm )-2-( $p$-Isobutylphenyl)propionate (12)

To a solution of $2(20 \mathrm{mg}, 0.056 \mathrm{mmol})$ in DMSO $(5 \mathrm{~mL})$, $30 \% \mathrm{H}_{2} \mathrm{O}_{2}$ aqueous solution $(265 \mu \mathrm{L}, 2.8 \mathrm{mmol})$ was added, with stirring. $\mathrm{FeSO}_{4} \cdot 7 \mathrm{H}_{2} \mathrm{O}(770 \mathrm{mg}, 2.8 \mathrm{mmol})$ was added by portions. After stirring for $1 \mathrm{~h}, 50 \mathrm{~mL}$ of water was added to the reaction mixture and extracted with ethyl ether three times. The combined organic layer was washed with brine and dried over anhydrous $\mathrm{Na}_{2} \mathrm{SO}_{4}$. After removing the organic layer in vacuo, the residue was purified by silica-gel column chromatography ( $n$-hexane/ether $=10: 1)$ to give $12(17 \mathrm{mg}$, $82 \%$ ) as a colorless powder.

Data of 12

Colorless powder. ESI-MS $(\mathrm{m} / \mathrm{z}) \quad 396 \quad(\mathrm{M}+\mathrm{Na})^{+}, \quad 374$ $(\mathrm{M}+\mathrm{H})^{+} .{ }^{1} \mathrm{H}-\mathrm{NMR}\left(\mathrm{CDCl}_{3}\right) \delta$ (ibuprofen moiety) $0.89(6 \mathrm{H}, \mathrm{d}$, $\left.J=6.8 \mathrm{~Hz}, \mathrm{CH}_{3} \times 2\right), 1.50\left(3 \mathrm{H}, \mathrm{d}, J=7.6 \mathrm{~Hz}, \mathrm{CH}_{3}\right), 1.84(1 \mathrm{H}, \mathrm{m}$, $\mathrm{H} 8), 2.43$ and 2.45 (each $\left.1 \mathrm{H}, \mathrm{s}, \mathrm{CH}_{2}\right), 3.71(1 \mathrm{H}, \mathrm{q}, J=7.6 \mathrm{~Hz}$, H2), 7.09 and 7.19 (each 2H, d, $J=8.4 \mathrm{~Hz}, \mathrm{ArH} \times 4$ ), (pyrroline moiety) 1.131 and 1.137 (each brs, $\left.\mathrm{CH}_{3} \times 2\right), 1.162(6 \mathrm{H}$, brs, $\mathrm{CH}_{3} \times 2$ ), 4.48 and 4.58 (each $1 \mathrm{H}, \mathrm{dd}, J=1.5,13.6 \mathrm{~Hz}, \mathrm{CH}_{2}$ ), 5.25 (3H, s, OMe). ${ }^{13} \mathrm{C}-\mathrm{NMR}\left(\mathrm{CDCl}_{3}\right) \delta$ (ibuprofen moiety) 18.39 (C9), 22.47 (C10), 30.31 (C8), 45.1 (C7), 45.3 (C2), 127.3 (C5), 129.4 (C4), 137.6 (3), 140.7 (C6), 174.4 (C1), (pyrroline moiety) $60.7\left(\mathrm{CH}_{2}\right), 67.5,69.7,132.2,139.1$. HR-MS $\left(\mathrm{ESI}^{+}\right)$ calcd for $\mathrm{C}_{23} \mathrm{H}_{36} \mathrm{NNaO}_{3} 396.25146$, found 396.25284.

\section{Analysis}

Apparatus

EPR spectra were obtained on a JEOL JES-FR30 EPR spectrometer. Samples were drawn into quartz capillaries, the bottoms of the capillaries were sealed and the capillaries were placed in standard 2-mm-i.d. quartz EPR tubes. The EPR spectrometer settings were as follows: microwave power, $4.0 \mathrm{~mW}$; frequency, $9.5 \mathrm{GHz}$; and modulation amplitude, 1.25 G. Quick mixing of sample was conducted by VOLTEX ${ }^{\mathbb{B}}$.

Reagents

The reagents used in this study were commercial products: L-ascorbic acid (Wako, Japan), and dimethyl sulfoxide (DMSO; Wako, Japan), 30\% $\mathrm{H}_{2} \mathrm{O}_{2}$ aqueous solution (Wako, Japan), and $\mathrm{FeSO}_{4} \cdot 7 \mathrm{H}_{2} \mathrm{O}$ (Wako, Japan). DMSO was deoxygenated by microwave under reduced pressure and used.

EPR Intensity Measurement of Time-Dependent Reduction of Six Nitroxides with 200-Fold AsA in DMSO Each sample 1-6 and ascorbic acid were dissolved in DMSO to prepare $2 \mathrm{~mm}$ stock solutions. Twenty microliters of $2 \mathrm{~mm}$ sample and $1.98 \mathrm{~mL}$ of ascorbic acid in DMSO were mixed by $\operatorname{VOLTEX}^{\circledR}$ and an EPR measurement taken after $2 \mathrm{~min}$. Subsequent measurements were taken at an interval of $1 \mathrm{~min}$ up to $10 \mathrm{~min}$, and then the interval was changed to $2 \mathrm{~min}$ until $30 \mathrm{~min}$ had passed.

The conditions of the EPR measurement were: field, $336.5 \mathrm{mT}$; power, $4.0 \mathrm{~mW}$; gain, 10.0 ; sweep width, $5.0 \mathrm{mT}$; modulation width, $0.1 \mathrm{mT}$; sweep time, $0.5 \mathrm{~min}$; time constant, $0.1 \mathrm{~s}$; date points, 0 ; accumulation, 1 ; accumulation method, no; and frequency, $9.2 \mathrm{GHz}$.

EPR intensity was calculated by following equation: 


$$
\begin{aligned}
& \text { EPR intensity } \\
& =\text { lowest peak height of the three line/ } \\
& \quad \text { peak height of the Mn marker }
\end{aligned}
$$

Twenty microliters of $2 \mathrm{~mm}$ nitroxide was diluted with $1.98 \mathrm{~mL}$ of DMSO to prepare $20 \mu \mathrm{M}$ sample solution. EPR intensity of $20 \mu \mathrm{M}$ sample solution was measured and the relative value of the EPR intensity was determined to be 1.0.

EPR Intensity Measurement of Time-Dependent Reduction of Five Nitroxides with Methyl Radicals in DMSO Methyl radical was prepared by the Fenton reaction. Thirty percent $\mathrm{H}_{2} \mathrm{O}_{2}$ aqueous solution was diluted with DMSO to prepare $4.04 \mathrm{mM} \mathrm{H}_{2} \mathrm{O}_{2}$ DMSO solution. Twenty microliters of each $2 \mathrm{~mm}$ sample DMSO solution and $1.98 \mathrm{~mL}$ of $4.04 \mathrm{~mm}$ $\mathrm{H}_{2} \mathrm{O}_{2}$ DMSO solution were mixed by VOLTEX ${ }^{\circledR}$ and the resulting mixture was used in the EPR measurement at 0 min. To this mixture, $2.2 \mathrm{mg}$ of $\mathrm{FeSO}_{4} \cdot 7 \mathrm{H}_{2} \mathrm{O}(8 \mu \mathrm{mol})$ was added and the mixture was mixed by $\operatorname{VOLTEX}^{\circledR}$ for $10 \mathrm{~s}$. An EPR measurement was taken on the resulting mixture.

The EPR measurement and the determination of EPR intensity were conducted in the similar way to the above described.

Conflict of Interest The authors declare no conflict of interest.

Supplementary Materials The online version of this article contains supplementary materials.

1. Chart S1. Synthesis of six nitroxides.

2. Figures S1-S5. ${ }^{1} \mathrm{H}-\mathrm{NMR}$ spectra of the nitroxides $\mathbf{1}-\mathbf{5}$ in $\mathrm{CDCl}_{3}$.

3. Figures S6-S11. EPR spectra of the nitroxides $\mathbf{1 - 6}$ in DMSO.

4. Table S1. Partition coefficients of nitroxides between $n$ octanol and PBS.

\section{References}

1) Ma Z., Huang Q., Bobbitt J. M., J. Org. Chem., 58, 4837-4843 (1993).

2) Miura Y., Nakamura N., Taniguchi I., Macromolecules, 34, 447-455 (2001).

3) Wetter C., Gierlich J., Knoop C. A., Muller C., Schulte T., Studer A., Chemistry, 10, 1156-1166 (2004).

4) Sakai K., Yamada K., Yamazaki T., Kinoshita Y., Mito F., Utsumi H., Tetrahedron, 66, 2311-2315 (2010).
5) Kinoshita Y., Yamada K., Yamasaki T., Mito F., Yamato M., Kosen N., Deguchi H., Shirahama C., Ito Y., Kitagawa K., Okukado N., Sakai K., Utsumi H., Free Radic. Biol. Med., 49, 1703-1709 (2010).

6) Yamasaki T., Mito F., Ito Y., Pandian S., Kinoshita Y., Nakano K., Murugesan R., Sakai K., Utsumi H., Yamada K., J. Org. Chem., 76, 435-440 (2011).

7) Yamasaki T., Ito Y., Mito F., Kitagawa K., Matsuoka Y., Yamato M., Yamada K., J. Org. Chem., 76, 4144-4148 (2011).

8) Khan N., Blinco J. P., Bottle S. E., Hosokawa K., Swartz H. M., Micallef A. S., J. Magn. Reson., 211, 170-177 (2011).

9) Paletta J. T., Pink M., Foley B., Rajca S., Rajca A., Org. Lett., 14, 5322-5325 (2012)

10) Rajca A., Wang Y., Boska M., Paletta J. T., Olankltwanit A., Swanson M. A., Mitchell D. G., Eaton S. S., Eaton G. R., Rajca S., J. Am. Chem. Soc., 134, 15724-15727 (2012).

11) Emoto M., Miho F., Yamazaki T., Yamada K., Akaba H. S., Hirata H., Fujii H., Free Radic. Res., 45, 1325-1332 (2011).

12) Kirilyuk I. A., Polienko Y. F., Krumkacheva O. A., Strizhakov R. K., Gatilov Y. V., Grigor'ev I. A., Bagryanskaya E. G., J. Org. Chem., 77, 8016-8027 (2012).

13) Morozov D. A., Kirilyuk I. A., Komarov D. A., Goti A., Bagryanskaya I. Y., Kuratieva N. V., Grigor'ev I. A., J. Org. Chem., 77, 10688-10698 (2012).

14) Emoto M. C., Yamada K., Yamato M., Fujii H. G., Neurosci. Lett., 546, 11-15 (2013).

15) Wang Y., Paletta J. T., Berg K., Reinhart E., Rajca S., Rajca A., Org. Lett., 16, 5298-5300 (2014).

16) Kajer T. B., Smith K. E. F., Yamazaki T., Yamada K., Fu S., Bottle S. E., Hawkins C. L., Davis M., J. Free Radic. Biol. Med., 70, 96-105 (2014).

17) Kinoshita Y., Yamada K., Yamasaki T., Sadasue H., Sakai K., Utsumi H., Free Radic. Res., 43, 565-571 (2009).

18) Emoto M. C., Sato S., Fujii H. G., Magn. Reson. Chem., 54, 705711 (2016).

19) Rozantsev E. G., "Free Nitroxyl Radicals," ed. by Ulrich H., Plenum Press, New York, 1970.

20) “Spin Labeling,” ed. by Berliner L. J., Academic Press, Inc., 1976.

21) Hatano B., Araya H., Yoshimura Y., Sato H., Ito T., Ogata T., Kijima T., HETEOCYCLES, 81, 349-356 (2010).

22) Morrow B. J., Keddie D. J., Gueven N., Lavin M. F., Bottle S. E., Free Radic. Biol. Med., 49, 67-76 (2010).

23) Galbo J. P., U. S. Patent, US5374729A (1993).

24) Ahn H.-Y., Smith K. E. F., Morrow B. J., Lussini V., Kim B., Bondar M. V., Bottle S. E., Belfield K. D., J. Am. Chem. Soc., 134, 4721-4730 (2012)

25) Chalmers B. A., Morris J. C., Smith K. E. F., Grainger R. S., Bottle S. E., Chem. Commun., 49, 10382-10384 (2013). 